『手話学研究』第 20 巻 (2011 年)

67 ページ〜 88 ページ

\title{
<原著 $>$
}

\section{日本手話における動詞補文の統語特性 \\ 一直接引用文との相違点を中心に}

\section{内堀 朝子 ${ }^{* 1}$ 松岡 和美 *2 南田 政浩 矢野 羽衣子 \\ ${ }^{* 1}$ 日本大学 ${ }^{* 2}$ 慶應義塾大学}

uchibori.asako@nihon-u.ac.jp

\section{1. はじめに}

自然言語に普遍的に観察される統語構造の一つに、文の中に別の文を埋め达む構 造、即ち、埋め込み (embedding) がある。埋め达みには、等位接続と従属接続と の二種類があり、従属接続には、付加と補部への埋め込みとがある。それぞれの音 声英語における例を、以下（1）および（2a-b）に示すが、本論文では日本手話にお ける（2b）と同じ種類の埋め込みについて、特に取り上げることとする。

(1) 等位接続［[John made lunch], [and Mary made dinner]].

(2) 従属接続

a. 文への付加 [[If Mary comes], John will make dinner]].

b. 補部埋め込み [John said [that Mary made lunch]].

（2b）では、補文標識 that から始まる埋め込み文が、主節動詞 said の補部の位置に 埋め达まれ、補文となっている1。

Chomsky（1957）以降の生成文法理論に基づく言語研究では、このような埋め込 みを含む構造において、自然言語の本質に関わる普遍的な統語的特性の一つである 「階層性」が見られるとされてきた ${ }^{2}$ 。即ち、文とは単に語や句が線状的に並んでで きたものではなく、語や句が階層的な構造を成して作られるものであって、それゆ え文の構成要素は互いに階層関係（つまり、構造において上下もしくは高低の関係） を持っているという特性である。従って手話言語にも「階層性」といった統語的特 性を示す埋め込みによる構造が見られるとすれば、手話言語が、埋め込み構造およ びそこで示されるのと同じ統語特性（即ち「階層性」）を有する他の自然言語と同種 の言語であると期待することは、自然である。 
生成文法理論における現在のアプローチとしてのミニマリスト・プログラム (Chomsky 1993, 1995, 2000, 2001 他) のもとでは、自然言語における「階層性」は 次のように説明されると考えられる。生物としてヒトは脳内に言語を生成するための 言語器官 (Language Faculty) を持ち、その言語器官において文を生成する際に、 2つの要素を結び付けて1つの要素を作る、併合（または結合）（Merge）と呼ば れる統語操作が行われているとする (Chomsky 1993, Hauser, Fitch and Chomsky 2002 他） ${ }^{3}$ 。併合が、一回の適用につき最大でも 2 つまでの要素を対象とする統語 操作であることによって、統語構造は二又枝分かれまでに限られ、三又以上の複数 枝分かれ構造は生成され得ないとすれば、そこから自然言語の統語構造に打ける「階 層性」は帰結する ${ }^{4}$ 。例えば動詞の補文埋め込みの場合は、併合が主文の構成要素 のうち主節動詞と補文の 2 つの要素に適用すれば、それ以外の主文の構成要素（例 えば主文主語）は、補文内の要素よりも構造上高い位置にあることになる。従って、 上で述べたように手話言語にも、これまで音声言語で一般に「階層性」が観察され ているのと同じ種類の埋め込み構造が存在するならば、それは、ミニマリスト・プロ グラムのもとでは、手話言語の生成にも他の自然言語の生成と同様の言語器官が関 与し、文を生成する統語操作として併合が適用されていることの帰結として説明で きることになる。

手話言語の先行研究では、例えばアメリカ手話に関して、Padden (1988) が、上の (1) のような等位接続と、(2b) のような補文の従属接続とが、それぞれ異なる種類の埋 め込みとして、統語構造的に区別されることを論じている ${ }^{5}$ 。また、松岡（2008）は、 アメリカ手話の動詞サンドイッチ構文を取り上げ、動詞主要部移動の有無と目的語 の移動の可否との関連を、階層的な動詞句（一致句を含む）構造とその構造に適用 される移動の制約とに基づいて、分析している。これらの埋め込み構造や階層的句 構造に関するアメリカ手話の研究は、そもそもアメリカ手話の統語構造が、上で述 べたように他の自然言語の場合と同様な仕組みで生成されていると見なせることを 示している。

日本手話については、埋め込みに関する先行研究として小谷（2009）があり、上 の（1）と同じ種類の埋め込み、即ち等位接続が扱われている。それによると、日本 手話の等位接続構造は、疑問化や話題化といった統語操作に伴う移動に関して、自 然言語に普遍的な等位接続構造制約（Ross 1967 を参照）に従っている。そこで本 研究では、日本手話統語論の基礎固めともなるよう、上の（2b）と同じ種類の埋め 込み、即ち従属接続のうち、動詞の補部位置への埋め込みである補文構造を取り上 げ、まず、補文埋め込みの存在を示すこととしたい。そのため、以下では特に、補 文と、一見それと類似しているが統語的には異なる構造を持っていると考えられる、 いわゆる直接引用文との相違について検討したい。直接引用文自体の統語構造や意 味解釈、また様々な引用形式などに関わる分析は本論文の目的ではないが、少なく 


\section{日本手話に打ける動詞補文の統語特性}

とも日本手話において補文およびそれとは異なる統語特性を示す直接引用文がある こと、また、両者の相違点は他の音声言語でも見られるものであることを指摘し、従っ て日本手話で両者を統語的に区別する必要があると論じる。日本手話が自然言語の 一つであることは言語獲得の面からも疑い得ないと考えられるが（鳥越（1995）、鳥 越(2008))、本研究の目的は、このことを統語的側面から、これまで観察されていなかっ たデータをもとにして明らかにしようとするものである。

2 節では、日本手話において「言う」のような発話伝達動詞による発話の内容を表 わす文として、他の自然言語同様、直接引用文とは異なる埋め込み文、即ち、補文 が存在することを、基本語順の違いおよび間投詞の分布に基づいて指摘する。 3 節 で、補文と直接引用文のそれぞれに対して、話題化の統語操作を適用できるかどう か検討し、補文には適用できるが、直接引用文には適用できないことを示す。4 節で は、同様にそれぞれに対して、WH 疑問化の統語操作を適用できるかどうか検討し、 補文には適用できるが、直接引用文には適用できないことを示す。最後に、5 節で結 論として、日本手話における埋め达み構造の一つとして、補文構造が存在すること を述べる。

\section{2. 補文と直接引用文の基本的相違}

\section{1. 語順}

本研究では，日本手話における単文である主文の基本語順を、市田（2005）に従 いSOV と考える。1節で見た音声英語の例（2b）と固有名詞を除いて同じ意味を表 わす日本手話の文は、以下（3）のとおりである ${ }^{6}$ 。なお、日本手話のみならず手話 一般における非手指動作の重要性は言うまでもなく、今後の研究においても、より 詳細に検討する必要があるが、以下の例文では表記を簡略なものとしているため?、 本研究で扱う現象に関与する場合を除き、非手指動作の記述を省略している。

（3） [ ${ }_{1}$ 林 ${ }_{2}$ 田中 弁当作る ]言う ] （日本手話）

一般に「言う」などの発話伝達動詞が選択する意味役割には、言う人である動作 主と、言われた内容である命題（平叙文の場合）がある。音声英語の例 1 節（2b） でも、主文主語John が動作主を、that 以下の補文が命題を、それぞれ意味役割と して担っている。同様に考えると、日本手話の（3）では、主文主語「林」が動作主を、 [ $\left.{ }_{2}\right]$ の埋め込み文が言われた内容を表わす命題を、それぞれ意味役割として担ってい ると見なすことができる。その場合、[2] の埋め込み文は、[1 ] の文全体の発話者が、 主文主語「林」の発話の内容だけを伝えた部分であり、「林」の発話の形式通りには なっていない。

ここで、発話を伝えるもう一つの方法として、言われた内容である命題を示すの 
ではなく、言われた言葉・発話をそのまま何も変えずに利用する直接引用と呼ばれ る方法があることに注意したい。例えば、以下の音声英語の例では、(4) がJohn に よる実際の発話で、途中で “...um....”と言い淀んだ部分を含んだものだとすると、(5) の[QUOT] の部分は、その言い淀みも含んだ、主文主語John の発話の形式そのまま の直接引用文となっている。

(4) Mary...um...made her lunch.

(5) John said, "[quor Mary ...um...made her lunch]."

これに対し、(4) の発話内容のみを補文として埋め込んでいるのが、1節（2b）の that 以下である。このように、音声英語では、補文を含む埋め込み $(1$ 節 $(2 \mathrm{~b}))$ と 直接引用文を含む構造（5）の違いとして、a）埋め达み文の文頭の補文標識 that の 有無、b）実際の発話特有の表現（言い淀みなどを表わす間投詞、後述）の有無が ある8。

それでは、音声英語の（5）の[QUOT] 内と比較して、日本手話の場合、上の例（3）の[2] 内は、以下（6）のような、（3）の主文主語「林」による実際の発話があったとして、 それをそのまま直接引用した文であると見なすことはできるだろうか。

（6）田中 弁当作る（日本手話）

この点は、音声英語の場合同様、実際の発話特有の表現が上の例（3）の [ 2$]$ 内に生 起できるかどうかを観察することによって、確かめることができると考えられる。ま ず、実際の発話特有の表現として、間投詞（又は感嘆詞、感動詞）があるが、間投 詞とは、例えば音声日本語では「もしもし」「お〜い」「はい」「あらあら」「ああ」な どで、呼びかけ・応答・驚き・感動などを表わし、単独で発話として現われること ができるが、主語・述語・修飾語といった文を構成する要素にはなれず、名詞や形 容詞といった主要な語彙範疇には属さない語である。一般に、発話の直接引用文に は、実際の発話に含まれる間投詞も当然そのまま含まれることがあるが、発話の内 容のみ即ち命題を表わ寸補文には、間投詞はその性質上当然現われ得ない。日本手 話で、以下（7）のような、「林」による間投詞を含む実際の発話があったとすると、 その発話そのままの直接引用文を含む文は、以下（8）のようになる。

（7）田中 $\mathrm{INT}_{\text {元っっと }} / \mathrm{INT}_{\text {あれっ }}{ }^{9}$ 弁当 作る ${ }^{10}$ （日本手話）

（8）[QuoT 田中 $\mathrm{INT}_{\text {え っと }} / \mathrm{INT}_{\text {あ九。 }}$ 并当 作る] 林 言う（日本手話） 


\section{日本手話に打ける動詞補文の統語特性}

（8）の[QUOT ] の部分は、音声英語の直接引用の例（5）の場合と同様、（7）と同じ間 投詞をそのまま含んでおり、（7）の発話をそっくりそのまま用いた直接引用文である と言える。

ここで、上の例（3）のような埋め込み文を含む場合と、（8）に示した直接引用文 を含む場合を比べると、日本手話母語話者にとって最も自然に感じられる語順（基 本語順）が、互いに異なっていることに気づく。上の例（3）の主文が、主語（動作 主）－目的語（埋め込み文）－動詞、即ちSOV という語順であるのに対し、(8) では、 主文の自然な語順は、目的語（直接引用文）－主語（動作主）－詞、即ち OSV とい う語順である。従って、上の例（3）では、語順からして [ $\left.{ }_{2}\right]$ の部分は上の（6）の発 話の直接引用文ではあり得ず、例えば上の（7）のような発話の内容のみを示した埋 め込み文であると考えられる。

以上に基づけば、上の例（3）と同じSOV 語順の文は補文埋め込みと考えられる ため、Oである [ $\left.{ }_{2}\right]$ の内部に、音声日本語の「え〜っと」「あれっ」等に相当する間 投詞を生起させると容認可能性が下がることが予測できる。この予測は、以下（9a-b） の対比によって裏付けられる。

（9） a. 先行文脈：田中さんと林さんは職場の同僚。この職場では、いつも誰かが弁 当を作ってくる。今日は、田中さんが弁当を作ってきた。林さんは、職場の他の 人にそのことを話していたのだが、すらすら言えずに途中で「え〜っと」などと、 つっかえて言っていた、もしくは、意外なことだったので途中で「あれっ」など と、驚きながら言っていた。

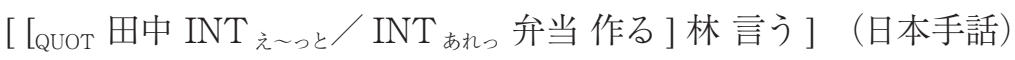

b. 先行文脈 : 田中さんと林さんは職場の同僚。この職場では、いつも誰かが弁 当を作ってくる。林さんは、田中さんが今日は仕事用のカバンの他にも、手提 げ袋を持ってきたのに気づいたようだ。私は、林さんがどう思うか分かったの で言った。

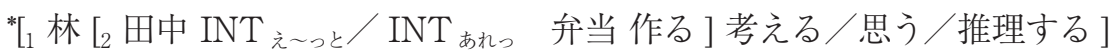

(日本手話)

（9）では、主文の動詞が、（9a）は発話伝達動詞「言う」、（9b）は思考動詞「考える ／思う／推理する」と異なっているが、これは、それぞれの目的語の文が、発話の 直接引用文である、あるいは、そうではなく内容のみを表わす文（補文）である、と いうことが文脈上もっとも想定しやすい動詞として、別々に用いた。従って（9b）の 
ような例文で主文動詞を「言う」に替えても、目的語である文を、発話の引用では なく内容のみを表わす命題として解釈する場合では、「考える／思う／推理する」の 場合と同じ容認可能性となる。

ここで、(9a) の語順は OSV であることから直接引用を、（9b）の語順は SOV で あることから補文埋め込みを、それぞれ含んでいることが分かる。（9a)では、先行 文脈で現われたとおりの「林」による発話が、間投詞を含めてそのまま引用され、かつ、 文の容認可能性に問題はない。一方、(9b) では、補文内に間投詞が現われており、 文は容認不可能となっている。つまり、(9ab) の対比は、間投詞本来の用法からし て自然に予測されると㧍り、間投詞が共起を許されているのは直接引用文の場合た けであることを示している。

な㧍、もし日本手話に打いて、音声英語の例（2b）と（5）の対比で見られたよう に、補文と直接引用文との間で補文標識に関して何らかの違いがあれば、それによっ て両者が区別できる可能性があった。しかしながら、日本手話には両者を区別する 補文標識に相当する音形 (手型または非手指動作)の違いは、存在しないようである。

日本手話の非手指動作については、関倸節や補文などの埋め込み文に伴うものが、 木村·市田 (1995)、高桑 (1997)、市田 (2005) などによって報告されている。市田 (2005) によれば、「田中 鈴木 弁当 作る 見る (日本手話)」のような文の中では、補文 の部分（この例では「鈴木 弁当 作る (日本手話)」）には「固定」という頭の動き が必要とされ、補文の終わりには頭を特定の位置で一瞬保持し、その後、文末の頭の 動きとして指定された位置に、素早く移動する（話者によっては、領きを伴う場合も ある)。また、高桑（1997）によれば、補文の場合は、補文の間では視線を冕らす動作、 補文末では逸らした視線を戻す動作および一瞬目を閉じたりうなずいたりする動作、 などが伴う。しかし、高桑（1997）は、それらの動作は、主文の語順がSOV の場合 と OSV に場合とで、違いがないとしている。上で明らかにしたとおり、SOV の語順 は補文埋め込み、OSV の語順は直接引用文を含むが、これら二通りの語順で非手指 動作に違いがないとすれば、これらの非手指動作が日本手話の補文標識にあたるもの だとしても、補文と直接引用文とで同じ形式を用いていると考えられる ${ }^{11,12}$ 。

まとめると、（8）や（9a）対（3）や（9b）に見られる語順の違いが、間投詞との 共起可能性と関係している事実は、日本手話において、これらの動詞の目的語となっ ている要素が、直接引用文の場合と補文の場合とで、統語的に異なって㧍り、目的 語となっている要素が主語の左右の任意の位置に許されているわけではない、とい うことを示している。以上から、自然言語一般に拉いて、「言う」などの発話行為に よる発話内容を表わす文法手段として、内容を意味する命題を表わす場合（補文）と、 発話形式をそのまま引用する場合（直接引用文）の二通りがあるが、日本手話にお いては、両者はそれぞれ基本語順が SOV と OSV とで異なり、従って統語構造的に も区別されていることが明らかとなった。 


\section{日本手話における動詞補文の統語特性}

\section{2. 統語操作の適用可能性}

補文と直接引用文には、前節で見た語順の違いに加え、一般に適用される統語操 作に関して根本的に異なる点がある。直接引用の場合は、引用された発話に何らか の統語操作を適用することはできない。実際の発話・セリフそのままを再現するもの である直接引用文に対して、何らかの変更を加えてしまうような統語操作の適用は、 そもそも不可能である。言い換えれば、文の派生において、直接引用文の構造は、 内部への統語操作の適用が許されないようなものであると考えられる ${ }^{13}$ 。一方、補文 では、内部に対する統語操作の適用が許される。補文の派生には、他の統語的制約 に違反しない限り、直接引用文の場合のような統語操作の適用に関わる制限は一切 ないと考えられる。

例えば、以下 (10-12)で示すように、音声日本語でかき混ぜ (scrambling) と呼ばれる、 移動を伴い語順を変える統語操作（10b）（Saito 1985 他多数）は、補文には適用で きるが（11）、間投詞を含むような直接引用文（主文主語「林」の発話の引用）には 適用できない $(12)$ 。

（10）a. 基本語順：田中が弁当を作った。

b. かき混ぜ操作適用後：弁当を田中が $\mathrm{e}^{14}$ 作った。

（11）弁当を林が [田中が e 作ると ] 言った。

(12）*弁当を林が [QUOT 田中がえ〜っと／あれっ e 作ると]言った。

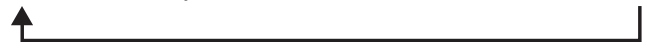

（12）のような直接引用文を含む例文が、具体的にどのような統語的制約に違反して いるかという問題に答えるには、直接引用文の構造を明らかにしなければならないが、 それは本論文の目的から外れるところが大きいため、今後の研究に委ねたい（注 13 も参照)。重要な点は、ここで見ている「言う」の類の動詞の目的語としては、かき 混ぜのような、統語構造を変える操作が適用できるもの（例えば（11））と、適用で きないもの（例えば（12)）の、二通りの構造を区別しなければならないという点で ある。ここで、日本手話の統語構造が、他の言語同様、自然言語としての統語操作 の適用によって派生されていると考えるならば、2.1節で見た日本手話の直接引用文 と補文の違いは、基本語順に関するだけでなく、統語操作の適用可能性においても 異なることが予測される。3 節以降では、話題化とWH 疑問化という統語操作につ いて、これを検証する。 


\section{3. 話題化の適用可能性}

本節では、話題化操作の適用可能性について検討する。話題化とは、文中のある 要素について、その文を発話する前に存在する文脈の中で、会話の参加者の間で既 にその要素の情報が共有されている場合、そのことを統語的に明示するための操作 を言う。

例えば、以下（13）に記述した先行文脈での発話に対して、別の人が続けて（14）（音 声日本語）や（15）（日本手話）を言ったとする。その場合、(13)・(14）または（13）・ (15）の会話の参加者は、(13)によって「弁当」という語が文脈上に既に出現し、弁当」 についての話が始まっていることを了解して抢り、そのため、(14）や（15）の文で、 「弁当」は話題（topic）として統語的に表示されていると見なすことができる。

（13）先行文脈：田中さんと林さんは職場の同僚。この職場では、いつも誰かが弁当 を作ってくる。今日は田中さんが弁当を作ってきた。私は職場の他の人達との 会話で、并当のことが話題になったので、次のように言った。

弁当と言えば…并当のことだけど…

（14）[Topic 并当は] 田中が e 作る。

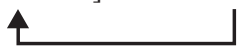

（15）[Tropic并当］田中 e 作る（日本手話）

音声日本語では（14）に見られるように、話題化された要素は文頭に移動し、話題 化のマーカーとして「は」が用いられる。日本手話では（15）に見られるように、話 題化された要素は文頭に移動し ${ }^{15}$ 、話題化のマーカーとして、少なくとも「目の見開き」 という非手指動作（例文では下線_で表示）が伴う。つまり、日本手話では、特定 の非手指動作が話題となっている語句に伴わなければ、文は容認不可能となる。

話題化は、移動を伴って語順を変え、かつ、新たな語（話題化のマーカー）が加 わるなど、直接引用文に適用された場合は、引用された元の発話が変更されてしま う統語操作であるため、前節で述べたとおり直接引用文には許されないことが予測 される。一方、補文にはそのような制約がないため、適用が許されることが予測される。 この予測について以下で検証しょう。

はじめに、音声日本語の場合を示しておく。以下（16）に記述した先行文脈での 「林」による発話があったとする。次にそれを受けて（17）で記述した文脈で発した 「私」の発話に続けて、更に別の人が（18）または（19）を言ったとする。（18）の[田 


\section{日本手話に打ける動詞補文の統語特性}

中が え〜っと／あれっ e 作ったと」の部分は、（16）の林の発話そのままであって、 間投詞も含まれていることから、直接引用文であると分かる。（19）については下で 述べる。

（16）先行文脈（2節（9）と同じ）：田中さんと林さんは職場の同僚。この職場では、 いつも誰かが弁当を作ってくる。今日は、田中さんが弁当を作ってきた。林さ んは、ついさっき、職場の他の人にそのことを話していたのだが、すらすら言 えずに途中で「え〜っと」などと、つっかえて言っていた、もしくは、意外な ことだったので途中で「あれっ」などと、驚きながら言っていた。

田中がえ〜っと／あれっ 弁当を作った。

（17）先行文脈（16の続き):林さんはついさっき（16）のセリフを言っていたのたが、 私は職場の他の人達との会話で、并当のことが話題になったので、次のように 言った。

弁当と言えば…弁当のことだけど…

（18）先行文脈（17 の続き）: 林さんがついさっき言った（16）のセリフを聞いていた 別な人が言った。

??[TOPIC 弁当は]ついさっき林が [QUOT 田中が え〜っと／あれっ e 作ったと ]

（19）先行文脈（17 の続き）: 林さんがついさっき言った（16）のセリフを聞いていた 別な人が、林さんがついさっき思っていた（とその人が判断した）ことを述べた。

[1 [TOPIC 弁当は ]ついさっき林が [2 田中が e 作ったと ] 思った ]。

まず、（18）と（19）の容認可能性を比べると、（18）の方が落ちる ${ }^{16}$ 。（18）では、文 頭の「弁当は」は、間投詞を含む直接引用文の中の要素が話題化されたものであり、 文全体の容認可能性が低下している。これに対し、（19）の［2田中が e 作ったと]の 部分は、間投詞がないからと言ってただちに直接引用文ではないとは言えないが（音 声日本語では、直接引用文と補文とで語順に差がないことに注意）、[2田中が e 作っ たと」の部分に含まれる要素が文頭に移動して話題化しており、それによって文全体 
の容認可能性は低下していない（つまり、容認可能である）。このことから、(19) の $I_{2}$ Jの部分は、（18）に扔ける直接引用文とは統語的に区別されるべき埋め込み文、即ち 補文であることが分かる。これは上で予測されたとおりである。

次に、日本手話の場合を確かめよう。以下、(20-23) は音声日本語(16-19) と同じ文脈· 発話の流れである。比べるべきは（22）－（23）の話題化を含む発話であり、(22）は 直接引用の形で「林」の発話（20）そのままを用い、(23）は補文として埋め込んで いる。直接引用文と補文は、間投詞の有無掞よび語順によって区別できる。

（20）先行文脈（2節 9 と同じ）：田中さんと林さんは職場の同僚。この職場では、い つも誰かが弁当を作ってくる。今日は、田中さんが弁当を作ってきた。林さんは、 ついさっき、職場の他の人にそのことを話していたのだが、すらすら言えずに 途中で「え〜っと」などと、つっかえて言っていた。

田中 $\mathrm{INT}_{\text {元っっと }}$ 并当作る（日本手話）

（21）先行文脈（20の続き):林さんはついさっき（20）のセリフを言っていたのだが、 私は職場の他の人達との会話で、并当のことが話題になったので、次のように 言った。

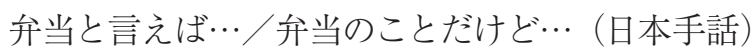

（22）先行文脈（21 の続き）：林さんがついさっき言った（20）のセリフを聞いてい た別な人が言った。

??[TOPIC 弁当] ついさっき [QuoT 田中 INT 元 っと $\mathrm{e}$ 作る] 林 言う（日本手話）

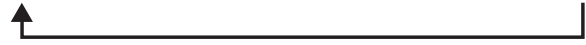

(23) 先行文脈 (21 の続き)：林さんがついさっき言った（20）のセリフを聞いてい た別な人が、林さんがついさっき思っていた（とその人が判断した）ことを述 べた。

[1 [TopIC 弁当 ] ついさっき 林 $[2$ 田中 e 作る $]$ 思う ] (日本手話)

（22）と（23）を比較すると、前者の容認可能性の方が低い ${ }^{17}$ 。従って、補文と直接 引用文を比べると、話題化の統語操作は、補文に対してのみ問題なく適用できるこ 


\section{日本手話に打ける動詞補文の統語特性}

とが確かめられた。このことは両者が構造的に異なっていること、更に、2. 2 節で見 たとおり、日本手話の補文の埋め込みが、発話の直接引用文とは違って、統語操作 を受けつける構造を持って派生されていることを示唆している。

\section{WH 疑問化の適用可能性}

本節では、WH 疑問化の適用可能性について検討する。WH 疑問化とは、文中の ある要素が分からない場合、それをWH 疑問詞に置き換えて疑問文を作る操作を言 う。以下（24a-b）に、肯定文と、その目的語をWH 疑問詞に置き換えた疑問文の日 本手話の例を示す。

（24）a. 田中 弁当作る（日本手話）

b. 田中作る 何 $($ 日本手話)

日本手話の WH 疑問文には一定の非手指動作として、木村・市田（1995:27）によれば 「眉を上げるか下げるかし、あごを前方か斜め前に突きだすようにし、あごを左右にこ きざみにふったりする」動きがある ${ }^{18,19}$ 。日本手話の WH 疑問化は、前節で見た話題 化と異なり、要素を移動することはないが、( $24 \mathrm{a})$ のような肯定文に相当する構造に 対して、WH 疑問詞に代入できる答えを求める（24b）のような疑問文に変えるための 統語操作が適用されていると考えられる。そうすると、2. 2 節で述べたとおり、文の派 生段階で適用される統語操作としての WH 疑問化は、補文内の要素には適用されて主 文がWH 疑問文となるが、直接引用文ではそれができないということが予測される。

まず、音声日本語の例でこれを示しておく。

（25）a. [1 林は [2田中が何を作ると ]思うの] ?

b. *[林は [QUOT 田中がえ〜っと／あれっ 何を作ると]言ったの] ?

（25b）の間投詞が林の発話によるもので、[田中がえ〜つと／あれつ何を作ると] が直接引用文となっている場合、このように WH 疑問化をすると容認不可能となる。

次に、日本手話について検証しよう。まず（26）に、記述した先行文脈のもとに 想定される補文埋め込みを含む肯定文を示す。

（26）先行文脈：田中さんと林さんは職場の同僚。この職場では、いつも誰かが弁当 を作ってくる。そして今日は、林さんは、田中さんが弁当を作ると思った。

[ ${ }_{1}$ 林 $[2$ 田中 弁当 作る ] 思う ] (日本手話) 
これに対し、以下（27）の状況で、（26）のような肯定文にWH 疑問化を適用したよ うなWH疑問文を作れるかどうか、確かめてみる。具体的には、(26)で主節動詞「思う」 の下に埋め达まれた補文である $\left[_{2}\right]$ 内の目的語「弁当」を、WH 疑問詞「何」に変え、 文全体をWH 疑問文にできるかどうかを調べる。

（27）先行文脈：林さんは、田中さんが何かを作ると思っているらしいが、私には、 林さんが田中さんが何を作ると思っているか分からないので、知りたい。そこで、 私は林さんと親しい人に尋ねてみた。

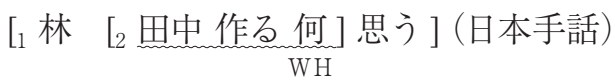

この文は容認可能であり、容認可能性はWH 疑問化を含まない（26）と変わらない。 次に、以下（28）の「林」による実際の発話を受けて、(29) の状況で（28）の発 話そのままにWH 疑問化を適用し、直接引用文を含む WH 疑問文を作れるかどうか を試してみると、例文が示すとおり、結果は容認不可能であることが分かる。

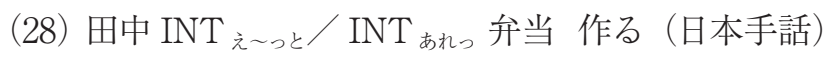

(29) 先行文脈: 私は、林さんが「田中 $\mathrm{INT}_{\text {え っと }} / \mathrm{INT}_{\text {あ九っ }} \sim$ 作る」と言っ ているのを見た。林さんは、すらすら言えずに途中で「え〜っと」などと、つっ かえて言っていた、もしくは、何か意外なことだったらしく途中で「あれっ」 などと、驚きながら言っていたが、〜のところは私のいる場所からよく見えず、 分からなかった。林さんが田中さんが何を作ると言っていたのか、私は知りたい。 そこで、林さんの言ったことが見える場所にいた人に、尋ねてみた。

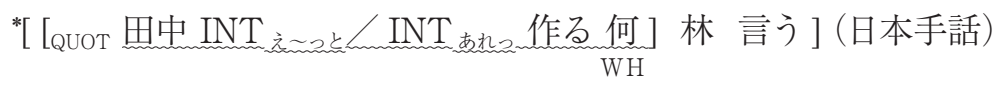

（27）と比べて（29）は母語話者の容認可能性が低く、即ち、直接引用文の WH 疑 問化は許されないことが分かる。

以上から、WH 疑問化という統語操作に関しても、補文には適用できるが、直接 引用文には適用できないことがことが、予測どおり確かめられた。従って、両者は 統語操作を受ける構造としては、区別される必要があると考えられる。 


\section{日本手話における動詞補文の統語特性}

\section{5. おわりに}

本論文では、日本手話における埋め込み構造のうち、動詞の補文である埋め込み 文を、直接引用文との比較に基ついて論じた。特に、両者は基本語順が異なり、また、 話題化と WH 疑問化の二つの統語操作の適用可能性において対照的であるという事 実を指摘した。これにより小谷(2009)の指摘する等位接続構造と併せて、日本手話に、 他の自然言語、例えば音声英語における埋め込み（1節（1）と（2b））と同様な二 種類の埋め込みによる統語構造が存在することが示された。従って、日本手話の生 成に関わる仕組みが、1節で述べたようなヒトの持つ言語器官およびそれによる併合 その他の統語操作の適用という観点から、他の自然言語と同様に説明できるように なることが期待される。

例えば、1節で述べたとおり、補文の埋め込みによる構造には、自然言語の統語 構造における普遍的かつ本質的特性の一つである「階層性」が見られると考えられる。 今後の研究で、日本手話の補文を含む統語構造に、一般に自然言語において階層構 造が深く関与することが知られている各種の統語現象がどのように現われているか、 観察することは興味深い。そのような統語現象の例として、自然言語における照応 表現や代名詞の分布は、束縛原理（Chomsky 1981）に従い、先行詞との間の階層関 係によって制限されていることが知られている。日本手話の代名詞や照応表現につ いても、埋め込み構造での分布を、例えば等位接続構造と補文構造とで比較しなが ら観察することなどにより、束縛原理にどのように従っているか（あるいは従ってい ないか）検証することができよう。

また、3 節、4 節で埋め达み構造からの話題化や WH 疑問化について見たが、日 本手話の話題化や WH 疑問化の分析を進めるには、移動の適用される統語環境を更 に詳細に観察していくことが必要である。特に、話題化のように要素の移動が伴う場 合、移動の距離がどのように制約されているか、他の自然言語と比較しながら検討 することは、今後の重要な課題である。ミニマリスト・プログラムでは、自然言語に 適用すると考えられる移動に関する制約として、統語操作によって文を生成する過程 (派生)において、経済性の原理が働いていると考えられている（Chomsky 1991 他)。 手話言語でも、移動に関わる統語操作が適用されるとき、どのような移動の局所性 が見られ、またそれがどのように派生の経済性の原理から説明されるかという問題は、 特に、派生されるものが音ではなく視覚上の言語形式として知覚され、同時に複数の 言語形式を表現する場（手指動作と非手指動作）を知覚できる可能性がある点から 考えると、興味深い。今後の研究で移動の伴う統語現象を観察する際には、本研究 で示したような動詞補文の埋め达みによる統語構造を用いることができよう。

以上のように、本研究を踏まえて、日本手話の統語現象に、自然言語の本質的か つ普遍的統語特性がいかに関与しているかについて、これからの研究が進んでいく ことを期待したい。 


\section{謝辞}

本論文は、第 36 回日本手話学会（平成 22 年 10 月 $30 \sim 31$ 日、於慶應義塾大学） で発表した論文「日本手話における埋め込み構造の予備的研究」を、発展させたも のである。学会参加者の方々との質疑応答により、貴重な示唆を得たことを感謝する。 また、『手話学研究』匿名査読者 2 名の方から、本論文の改稿に際し、有益なコメン トをいただいたことを感謝する。

本研究は、平成 $20 \sim 22$ 年度科学研究費補助金萌芽研究（課題番号 20652029）「自 然言語としての日本手話の統語分析：ネイテイブサイナーの言語知識」（研究代表者： 松岡和美)の助成を受けた。また研究を進めるにあたって、手話通訳の仁木美登里氏、 山方純子氏、須田ちえ子氏に多大なご助力をいただいたことに、感謝の意を表したい。

\section{注}

（1）では、等位接続詞 and によって 2 つの文が主文に埋め达まれ、（2a）では、 従属接続詞if から始まる条件節である従属文が、主文に付加されることによって埋 め达まれている。

2 埋め込みには、「階層性」の他に、自然言語の普遍的・本質的な統語特性である「回 帰性」が典型的に観察されることが知られている。即ち、埋め込みは原理的には回 帰的に、つまり無限に繰り返すことが可能であり、それによって無限の長さの文を生 成し得る (注 4 も参照)。

なお、匿名査読者の指摘のとおり、近年、埋め込み構造を持たないとされる自然言 語(例えばピラハー語)も存在すると論じられている(Everett 2005 など)。本論文では、 補文埋め込み構造に典型的に見られるような「階層性」が、自然言語の普遍的特性 に含まれるべきかどうかについて検証することを目的としないが、少なくとも、日本 手話において直接引用文とは異なる統語特性を示す文の埋め达みが観察されることを 指摘することによって、日本手話が、補文の埋め込み構造を有する他の自然言語全て と同じ統語的特性（即ち「回帰性」および「階層性」）を有していると論じる。

埋め込み構造を持たないとされる言語であるピラハー語については、藤田（2009） は「回帰性」は見られると論じ、池内（2010）は「回帰性」がないとしても「階層 性」はあると主張している。いずれにしても、藤田（2009）や池内（2010）も述べ ているように、「回帰性」や「階層性」が、自然言語に唯一許される統語操作として の併合から必然的に導かれる統語特性であると考えれば（本文後述および注 3、注 4 も参照)、日本手話にも多くの他の自然言語にも存在する埋め込み構造に見られる「階 層性」ないし「回帰性」は、自然言語に許される統語操作の適用によって必然的に 生じ得る統語特性であるという点で、少なくとも、自然言語の本質的特徴の一部（あ るいは許される本質的特徴のバリエーション）であると見なすことができる。

3 Chomsky（1993）によれば、統語操作の適用対象である語彙項目 $a$ と $\beta$ に併 


\section{日本手話に打ける動詞補文の統語特性}

合が適用されると、その結果、両者による集合が作られ、かつ、その集合にはラべ ルが与えられる。ラベルは常に $\alpha$ か $\beta$ のどちらかと同じものになる。つまり、 $\alpha$ と $\beta$ に併合が適用された結果として $\{\gamma(\alpha, \beta)\}$ という集合ができる（ $\gamma$ はラべ ルを表わす)。例えば、音声英語で限定詞 the と名詞boy に併合が適用して限定詞 句 the boy ができるが、実態としては，the，(the, boy）；という集合が作られたと考 える(なお、併合が付加移動に伴って生じる場合、結果として得られる集合が若干 異なる (Chomsky 1995))。

4 なお注 2 で言及した「回帰性」についても、併合が原理上回帰的に適用され得る 統語操作であるとすれば必然的に導かれる。

5 Padden（1988）によれば、アメリカ手話では、等位接続と補文は以下の 4 点にお いて異なっている。（1）補文には文末に主語と同じ指示対象を持つ代名詞が現われ ることができるが、等位接続ではできない、(2) 否定の標識である非手指動作の首 振りは、補文を伴う主文に出現した場合、補文の文末まで継続するが、等位接続の 最初の文に出現した場合、後続する文にまで続くことはできない、（3）補文からの 話題化は可能だが、等位接続からの話題化は不可能、(4) 等位接続詞が等位接続さ れた文の文頭に現われることはあるが、補文の文頭に現われることはできない。こ れら 4 種類の統語現象のうち、日本手話についても当てはめられるのは、話題化の みである。例えば、否定の首振りは、アメリカ手話と日本手話では異なる分布を示す。 本論文では、3 節で話題化について取り上げる。

6 以下の日本手話例文の容認可能性判断は、文法分析の基礎訓練を受けているろう 者（ネイティブサイナー、デフファミリー出身）男女 2 名（南田・矢野）によっている。 7 以下の日本手話例文中の各語に対しては、意味的に対応すると考えられる音声日 本語の単語を記している。なお、動詞に対して、便宜上、書記／音声日本語におけ る動詞のいわゆる「る」形（非過去形）を用いているが、日本手話の動詞は形態的 な時制変化を示さないため、例えば（3）の「言う」という表記は、日本手話の動詞 が書記／音声日本語の非過去時制と同様の時制形態を担っていることを表わすもの ではない。

日本手話の例文に対する適切な表記法としては、例えばアメリカ手話を始め他の 手話言語を分析した文献などにも広く見られるように、日本手話の各語に意味的に 対応する音声英語の単語、とくに全て形態変化を伴わない形の英単語を用いること とし、機能範疇や、各語の統語素性・意味素性・形態素性および非手指動作などは それらの内容・機能を示す言語学上の術語を略語表記することによって表わすやり 方があろう。しかしながら本論文では、『手話学研究』所収論文の多くにおいてそ のような表記が一般的ではないことを考慮して、例文表記に書記日本語を利用した。 適切な例文表記方法は、日本の手話言語学研究における今後の課題と考えられる。

8 なお、音声言語において発話を直接引用するためには様々な文法手段があり、匿 
名查読者の指摘するとおり、例えば補文と直接引用文を融合させたような mixed quote (Cappelen and Lapore 1997) と言われるような種類の引用文もあるとされるが、 1節で述べたように本研究の射程には、「引用」という文法形式そのものの詳細な分 析は含まれないため、ここでは、統語特性上で異なる二種類の埋め込み文について、 一方を直接引用文、他方を補文埋め込みと見なしている。

重要なのは、仮に日本手話に扔ける引用形式が、音声英語に見られる直接引用文 とは異なる構造（例えば mixed quote）であったとしても、その構造如何に関わらず、 日本手話に扔いて、引用の場合とは異なる統語特性を示す、別の種類の埋め込み文 が存在するという点であり、その埋め込み文の示す統語特性は、特に内部からの抜 き出しに関して、他の音声言語の補文埋め込み構造と共通の性質を示す、という点 であることに留意されたい。

9 INT は間投詞 (interjection)。ここでは、「INT え っと」は、音声日本語で言い淀み・ 言う前のためらいなどを表わす「え〜っと」等に相当し、「INT あれっ」は、音声日本 語で意外なことへの驚きなどを表わす「あれっ」等に相当する手話表現（非手指動 作を含む) とする。後者の手指動作には、筆者らが観察した限り三種類があったが(例 えばそのうちの一つは、右手の親指と人差指で口を開いたままの下顎を触ってから、 開いた左手の手のひらに下ろして素早く吒く)、全てに共通する非手指動作として「目 の見開き」「口をアーと開く」が同時に伴う（日本手話に拐ける口型に関しては、木 村 (2011)、木村·市田（1995）、松岡他（2010）、坂田 · 矢野 · 米内山 (2008)、手 話文化村（2006a, b) を参照)。

10 本論文で挙げた INT を含むどの例文でも、INT を文頭に置く場合が最も自然で あると日本手話母語話者によって判断され、構造を明らかにするため INTを文中に 置く語順では、それだけで若干違和感があるとされている。以下では、その不自然 さは容認可能性判断としては表示していない。

なお、INT が主文ではなく埋め込まれた文の中に置かれている例文では全て、母 語話者に、その INT を文全体の話者による言い淀みや驚きを表わすためのものでは なく、INT を直接含む文の話者・発信者（本論文では常に主文主語）によって発話 されたもの、即ち、埋め込まれた文の中に生起しているものと解釈してもらい、その 上での判断を聞いた。もし母語話者が文中の INT を主文全体の話者によって挟み込 まれたものと解釈すれば、言い換えると、その INT の存在が埋め込み文を直接引用 文であることを示していないものと解釈した場合は、例文の容認可能性が上がるこ とが予測される。実際、INTをそのように解釈した場合、本論文で低いと報告した 例文の容認可能性は全て上がる。

11 従って、例文表記上、補文と直接引用文に伴う非手指動作は両者の区別に関わら ないため、省略している。言うまでもないが、埋め込み文に伴う非手指動作に関し ては、今後更に詳細な検討が必要である。 


\section{日本手話に打ける動詞補文の統語特性}

12 音声日本語でも、埋め达み文の文末形式が、補文でも直接引用文でも同じ「と」 という音形を持ち、区別できない。更に、基本語順に関しても、補文を含む構造と 直接引用文を含む構造で変わらない。そのため、例えば「林が田中が弁当を作った と言った」というような例文において、「田中が弁当を作った」の部分が補文である か、あるいは、間投詞などをたまたま含まない実際の発話の直接引用文であるかは、 このままでは区別できない。音声日本語では、間投詞がなく、また、次節 2.2 で見 るような、語順の変化をもたらすような統語操作の適用がない場合は、補文と直接 引用文のどちらの可能性もあり得る。

13 直接引用文が外部からの統語操作を受け付けない理由については、Chomsky (2000, 2001 他）の提案する派生の相（phase）の概念に基づくと、以下のように説明 できる可能性がある。即ち、直接引用文を、通常の時制文として強い相主要部 (strong phase head）である補文標識の投射であるというだけでなく、それがもう一つ別の「引 用標識」(quotation marker) とも言うべき強い相主要部によって選択されている左 端部 (left periphery) 構造を持つと仮定しよう。そうすると、その構造（例えば [QUOTP 引用標識 [CP 補文標識 ... ]]) では、相不可侵条件 (phase impenetrability condition) (こ こでは Chomsky（2001）による定義を想定するが、詳細は省く）に従って、引用さ れた文（[CP 補文標識 ... ] ] ) の内部が、それを選択している主要部（引用標識）とそ の周縁部を除いて、外部からの統語操作を受け付けることができない。一方、同じ 条件のもと、補文は CP 構造（[CP 補文標識 ... ] ) を持ち、主要部である補文標識の 周縁部を利用して、外部からの統語操作を受け付けることができる。

なお、匿名査読者の指摘のとおり、このような分析のもとで直接引用文と補文の 基本語順の違いはどのように説明できるかという問題は、まだ残されている。そこで、 上の分析からは離れるが、この問題と関係するかもしれない点を挙げておくと、筆 者らの調査した複数のろう者（日本手話母語話者）の判断によれば、文の要素に付 加詞が含まれる場合、付加詞を文頭に置く語順が好まれる傾向がある。例えば、音 声日本語の「熊がきつねに昨日森で魚をあげた」の意味におおむね対応する、以下 の日本手話の例文（i-ii）を比較すると、(ii）の語順の方がよいと感じるという。

(i) 熊きつね 昨日 森 魚 あげる (日本手話)

(ii) 昨日 熊 きつね 森 魚 あげる (日本手話)

そうすると、もし直接引用文が補文と異なり、動詞の補部（内項）ではなく、付加 詞であるとすれば、そのことが直接引用文が文頭に現われる理由かもしれない。さ らに、もし直接引用文が付加詞であるとすれば、別の匿名査読者が指摘するように、 内部からの抜き出しが許されない事実も、付加詞からの移動を阻止するような、一 般的な（他の音声言語にも共通する）移動の制約（いわゆる「島の制約」、ミニマリ 
ストプログラムに基づく島の制約の分析については Takahashi (1994)、Hornstein （2001）、Boeckx（2003）などを参照）によって説明できる可能性もある。直接引用 文や補文の構造に関しては、今後もより詳しいデー夕収集を始めとして、更に研究 を進める必要がある。

14 統語操作としての移動（Move あるいは Internal Merge）によって、ある要素が 元の位置から構造的に高い位置に動かされ、元位置には要素のコピーが残る。通常、 複数生じたコピーはその内一つを除いて音形を持たないとされる。以下の例文で、 $「 \mathrm{e} 」$ は音形を持たないコピーを表わす。

15 話題化に伴う文頭への移動は、他の言語でもよく見られる。例えば音声英語でも、 文頭への移動が生じる。話題化のマーカーとしては、音声英語では何もない場合と“as for”が用いられる場合の両方がある。

16 例文（18）と（19）では主文の動詞が（18）「言う」と（19）「思う」で相違して いるが、前節（9ab）の場合同様、目的語の文が、発話の直接引用である、あるいは、 そうでない補文（いわゆる間接引用）である、ということがそれぞれもっとも想定し やすい動詞として用いた。

また、(18）（19）の「ついさっき」は、移動された要素（ここでは「弁当は」）が、 主文の最左端（即ち主文先頭）の位置まで移動していることを示すために主文主語 の左に挿入された副詞であり、修飾している述部は主文動詞「思った」である。(18) （19）の容認可能性の差は、「ついさっき」にあたる副詞を削除しても、基本的に変 わらない。以下の（i）(ii）を比較されたい。

(i) [弁当は]林が [田中が e 作ったと]思った。

(ii)??[弁当は]林が [田中がえ〜っと/あれっ e 作ったと] 言った。

なお、（18）の容認可能性の低さは、話者や例文によってはそれほど低く感じられ ない場合がある（注 10 も参照）。しかし、引用されたセリフに間投詞などを入れれ ば入れるほど、即ち、直接引用であることが明確に判断できればできるほど、容認 不可能であることが分かり、（19）との差が大きくなる。例えば音声日本語の例で、

(iii）先行文脈:ついさっき、林さんが、「へえ〜お前らの弁当は田中が全部作るのかよ」 と言っていたので、私は他の人達との会話で弁当のことが話題になったとき、 次のように言った。

*?[ お前らの弁当は]ついさっき林が [へえ〜田中が $\mathrm{e}$ 全部作るのかよ]と言った。 


\section{日本手話に打ける動詞補文の統語特性}

などの場合は、容認可能性が非常に低いことが明らかである。この事実は、直接引 用文の内部の要素を文頭に抜き出すというような、直接引用文の構造を変えるような 統語操作は許されないことを明確に示している。

17 なお 2.1 節（9ab）についての本文および注 16 でも述べたとおり、（22）（23）の 主文動詞の違い（「言う」と「思う」）は、それぞれ動詞目的語の適切な解釈（発話 の引用か、内容を表わす命題か）のもとでは、容認可能性判断に影響しない。

（22）の容認可能性の低下の程度については、音声日本語の場合について注 16 で 述べたのと同様、もともと日本手話でも直接引用文の要素の話題化に対する容認可 能性判断は、あまり厳しくないようである。これまでに用いたINTのうち「INT れっ」の場合、母語話者によれば、ほぼ容認可能であるとされた（注 9 で触れた三種 類のうちどの場合でも同じ)。「INT あれっ」含む直接引用文からの話題化も、注 16 (i) と同様な、発話そのままの引用であることを保証するような表現を複数用いてテスト するのが望ましいが、本研究では、日本手話において用いることができるその種の 適切な表現が見つからなかった。

18 例の波線部は、WH 疑問文に伴う非手指動作の出現範囲を示す。ここで、(24b) ではそのような非手指動作が主語「田中」を含む全文に及ぶ場合を示しているが、 主語を含まない場合も可能である。以下の例文でも、非手指動作の可能な出現範囲 は複数あるが、そのうち最長の場合のみを波線で示している。

なお、このようにWH 疑問文において WH 疑問詞を含む一定の範囲に何らかの標 識が生起することは、他の自然言語でも観察される。例えば、音声日本語の WH 疑 問文では、日本手話と同様 WH 疑問詞は移動しないが、文末に疑問文特有の補文標 識（「か」や「の」）が現われることがあるとともに、一定のイントネーション（音調 の上がり下がり）がWH 疑問のスコープ解釈に関係していることが指摘されている (Deguchi and Kitagawa 2002, Ishihara 2002)。日本手話の WH 疑問文に生じる非手 指動作とWH 量化子のスコープの関連については、高桑(1997)が詳細を分析している。 19 本研究では、目的語が WH 疑問詞となる場合のみ扱う。日本手話の WH 疑問文 の構造については、高桑（1997）が分析している。そこでの例（およびそこで引用 されている他の先行研究の例）が示しているように、本文に示した以外の WH 疑問 文の語順として、以下（非手指動作の範囲に関しては、注 18 を参照）がある。

（i）a. 田中 何作る

b. 田中 何作る 何

WH

つまり、日本手話の目的語 WH 疑問文は（24b）を含め、語順だけで 3 通り、また、 非手指動作の出現範囲が全文の場合と主語を除く場合の 2 通りの可能性を含めると 
全部で 6 通りあり得るが、本研究ではスペースの都合上全ては列挙せず、(24b) の パターンに準じて、以下示すこととする。日本手話の WH 疑問文の構造については、 非手指動作の可能な出現範囲も含めて更に検討が必要であり、今後、詳しく研究す る予定である。

\section{参考文献}

Boeckx, Cedric (2003). Islands and Chains. Amsterdam: John Benjamins.

Cappelen, Herman and Ernie Lapore (1997). "The varieties of quotation," Mind 106:429-450.

Chomsky, Noam (1957). Syntactic Structures. The Hague: Mouton.

Chomsky, Noam (1981). Lectures on Government and Binding. Dordrecht: Foris.

Chomsky, Noam (1991). "Some notes on economy of derivation and representation," in Robert Friedin (ed.), Principles and Parameters in Comparative Grammar, Cambridge, 417-454. MA: MIT Press.

Chomsky, Noam (1993). "A minimalist program for linguistic theory," in Hale, Ken and Samuel J. Keyser (eds.), The View from Building 20: Essays in Linguistics in Honor of Sylvain Bromberger, 1-52. Cambridge, MA:MIT Press.

Chomsky, Noam (1995). The Minimalist Program. Cambridge, MA: MIT Press. Chomsky, Noam (2000). "Minimalist inquiries," in Martin, Roger, David Michaels and Juan Uriagereka (eds.), Step by Step: Essays on Minimalist Syntax in Honor of Howard Lanisk, 89-155. Cambridge, MA. MIT Press.

Chomsky, Noam (2001). Derivations by phrase, in Michael Kenstowicz (ed), Ken Hale: A Life in Language, 1-52. Cambridge, MA. MIT Press.

Deguchi, Masanori, and Yoshihisa Kitagawa (2002). Prosody and wh-questions, in Hirotani, Masako (ed.), NELS 32: Proceedings of the North East Linguistics Society 1: 73-92. Amherst, MA: GLSA, University of Massachusetts, Amherst.

Everett, Daniel (2005). "Cultural constraints on grammar and cognition in Pirahã: Another look at the design features of human language," Current Anthropology 46: 621-646.

藤田耕司 (2009). 「言語の起源と進化正 生成文法の視点から」, 池内正幸 (編) (2009), 『言語と進化・変化』, 95-133. 東京: 朝倉書店.

Hauser, Marc D., Noam Chomsky, and W. Tecumseh Fitch (2002). “The faculty of language: What is it, who has it, and how did it evolve?", Science 298: 1569-1579.

Hornstein, Norbert (2001). Movel A Minimalist Theory of Construal. Oxford: Blackwell.

市田泰弘 (2005). 「手話の言語学 (10) 文構造と頭の動き一日本手話の文法 (6)「語順、 補文、関係節」,『月刊言語』34(10): 91-99. 


\section{日本手話に打ける動詞補文の統語特性}

池内正幸 (編) (2009). 『言語と進化・変化』. 東京 : 朝倉書店.

池内正幸 (2010).『ひとのことばの起源と進化』. 東京：開拓社.

Ishihara, Shinichiro (2002). "Invisible but audible wh-scope marking: Whconstructions and deaccenting in Japanese," in Mikkelsen, Line and Chris Potts (eds.), Proceedings of the 21st West Coast Conference on Formal Linguistics (WCCFL 21), 180-193. Somerville, MA: Cascadilla Press.

木村晴美 (2011).『日本手話と日本語対応手話(手指日本語) : 間にある「深い谷」』. 東京: 生活書院.

木村晴美・市田泰弘 (1995).『はじめての手話』. 東京：日本文芸社.

小谷克則 (2009).「日本手話における等位構造」,『日本手話学会第 35 回大会予稿集』 33-36.

松岡和美 (2008).「動詞上昇を用いたアメリカ手話構文の統合的分析」、『手話学研究』 17: 69-83.

松岡和美・南田政浩・矢野羽衣子 (2010).「日本手話における口型の予備的研究」,『日 本手話学会第 36 回大会予稿集』21-22.

Padden, Carol A. (1988). Interaction of Morphology and Syntax in American Sign Language. New York: Garland Press.

Ross, John R. (1967). "Constraints on variables in syntax," Ph.D. thesis. MIT. [published 1986 as Infinite Syntax!, Norwood. NJ: Ablex.]

坂田加代子 · 矢野一規・米内山明宏 (2008).『翻訳で変わる日本語と手話の関係 : 驚 きの手話「パ」「ポ」翻訳』.大阪：星湖舎.

Saito, Mamoru (1985). "Some asymmetries in Japanese and their theoretical consequence," Ph.D. thesis. MIT.

Sandler, Wendy, and Diane Lillo-Martin (2006). Sign Language and Linguistic Universals. Cambridge: Cambridge University Press.

手話文化村 (2006a).『手話口型の役割 NO.1 (DVD)』. 東京：手話文化村 .

手話文化村 (2006b).『手話口型の役割 NO.2 (DVD)」. 東京 : 手話文化村.

Takahashi, Daiko (1994). Minimality of Movement, Unpublished doctoral dissertation, University of Connecticut, Storrs.

高桑香織 (1997). 「手話の統語論一日本手話の wh 疑問文について一」,『東京女子大 学言語文化研究』6:64-81. 東京女子大学.

鳥越隆士 (1995).「万う児はいかに手話を学ぶか」, 『手話学研究モノグラフ5』1-61. 日本手話学会.

鳥越隆士 (2008).「手話の獲得」，小林春美・佐々木正人（編）『新・子どもたちの言 語獲得』231-258. 東京 : 大修館書店.

- 2011 年 6 月 2 日受理、 2011 年 11 月 1 日掲載決定- 


\title{
On syntactic differences between complement clauses and direct quotations in Japanese Sign Language
}

\author{
Asako Uchibori ${ }^{1}$, Kazumi Matsuoka ${ }^{2}$, \\ Masahiro Minamida, Uiko Yano \\ ${ }^{1}$ Nihon University, ${ }^{2}$ Keio University \\ uchibori.asako@nihon-u.ac.jp
}

\begin{abstract}
Since Japanese Sign Language (JSL) is a human language, as clearly shown by previous studies, it should be possible for JSL to have a hierarchical structure that can be generated as a result of the application of syntactic operations. This paper deals with one such case, i.e. embedding a clause into a verb complement position, and is aimed at developing a solid basis for the syntactic analysis of JSL. In order to confirm that JSL actually has a complement structure, clauses selected by a verb of saying and thinking were compared with direct quotation clauses. The differences examined in this paper concern word order, the possibility of topicalization, and the possibility of $\mathrm{WH}$-question formation. The basic word order of a sentence with a complement clause is SOV, whereas that with a direct quotation is OSV. A sentence with a complement clause allows topicalization and WH-question formation, while one with a direct quotation does not allow either of them. The difference in the grammatical acceptability of topicalization and WH-question formation suggests that a sentence with a complement clause can undergo syntactic operations such as Move (or Internal Merge), whereas one with a direct quotation clause cannot.
\end{abstract}

